\title{
Swindon, we have a problem
}

\section{Britain's space ambitions lack financial fuel.}

\section{BY GEOFF BRUMFIEL}

$\mathrm{F}$ or someone in charge of a brand new space agency, David Williams has had a prosaic year. Rather than standing in front of banks of computers, watching the test launch of a bold new rocket design, the interim director of the UK Space Agency (UKSA) has been shuffling between almost a dozen government entities, arranging the transfer of budget lines and staff members. "Most of what we've done this year has been internal," he says.

The UKSA was announced with much fanfare in March 2010, but its low-key start and lacklustre annual budget of $£ 206$ million (US\$332 million; $€ 241$ million, see chart) has left some disappointed. "At the moment,

品 we're not happy," says Richard

Peckham, the chair of UKspace, the industry's trade association.

"But it’s still early days."

Britain has a difficult history

in space. The country launched its first - and only - entirely

home-grown rocket into orbit

in 1971, but even before it flew

the government had decided to kill the programme to cut costs.

More recently, the 2003 failure of the Beagle 2 Mars probe left the nation's pride smarting. Despite these setbacks, the country's private sector has made steady progress. Between 1999 and 2007, the space industry grew by a steady $9 \%$ per year and today boasts about $£ 6$ billion in annual revenues. Much of that money is made by small satellite manufacturers and telecom companies offering satellite-phone and Earthobserving capabilities.

Until last year, the nation's space agenda which included environmental satellites and a few collaborative missions with the European
Space Agency (ESA) - was overseen by the British National Space Centre (BNSC), a somewhat toothless organization, also run by Williams. "Different government departments held the budget for the bits of space they were interested in," says Peckham. "The BNSC partnership tried to glue that together."

Industry wanted a more powerful agency, along with an increased focus on space as an area of economic growth and innovation. The then Labour government agreed and created the UKSA, along with a space innovation centre at Harwell in Oxfordshire - where a new ESA centre had just been sited - that included a $£ 40$-million national space facility.

But as the Swindon-based UKSA prepares to officially open for business on 1 April, it has yet to put forward a clear plan. "We are still waiting for the emergence of a confirmed UK space strategy," says Martin Ditter, head of the ESA centre at Harwell.

The slow start is largely due to the ousting of the Labour government in May 2010. In December, the new coalition government announced that, as part of its austerity programme, the overall UKSA budget for the next four years would be almost flat. That makes it unlikely that the agency will launch its own spacecraft any time soon, although researchers hope that its unifying voice will help Britain to negotiate more prominent roles in ESA science missions.

"Against the backdrop of $25 \%$ cuts in government spending, they've probably done a pretty good job," says Peckham. But there is a tinge of disappointment in his voice as he adds, "It doesn't yet look like the empowered agency that we want to see."

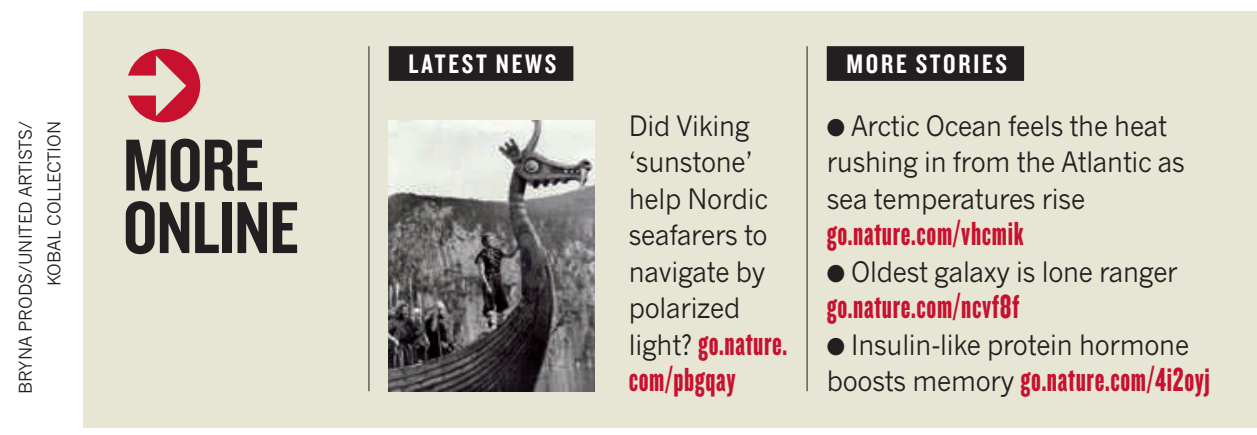

